\title{
Assessment of first molars sagittal and rotational position in Class II, division 1 malocclusion
}

\author{
Paulo Estevão Scanavini¹, Renata Pilli Jóias², Maria Helena Ferreira Vasconcelos ${ }^{3}$, \\ Marco Antonio Scanavini4 , Luiz Renato Paranhos ${ }^{5}$
}

Objective: This study assessed the anterior-posterior positioning of the upper and lower first molars, and the degree of rotation of the upper first molars in individuals with Class II, division 1, malocclusion. Methods: Asymmetry I, an accurate device, was used to assess sixty sets of dental casts from 27 females and 33 males, aged between 12 and 21 years old, with bilateral Class II, division 1 . The sagittal position of the molars was determined by positioning the casts onto the device, considering the midpalatal suture as a symmetry reference, and then measuring the distance between the mesial marginal ridge of the most distal molar and the mesial marginal ridge of its counterpart. With regard to the degree of rotation of the upper molar, the distance between landmarks on the mesial marginal ridge was measured. Chi-square test with a 5\% significance level was used to verify the variation in molars position. Student's t test at $5 \%$ significance was used for statistical analysis. Results: A great number of lower molars mesially positioned was registered, and the comparison between the right and left sides also demonstrated a higher number of mesially positioned molars on the right side of both arches. The average rotation of the molars was found to be $0.76 \mathrm{~mm}$ and $0.93 \mathrm{~mm}$ for the right and left sides, respectively. Conclusion: No statistically significant difference was detected between the mean values of molars mesialization regardless of the side and arch. Molars rotation, measured in millimeters, represented $1 / 4$ of Class II.

Keywords: Molar tooth. Angle Class II malocclusion. Orthodontics.

Objetivo: esse estudo avaliou o posicionamento anteroposterior dos primeiros molares superiores (1ำ MS) e inferiores, e o grau de rotação dos $1^{\circ} \mathrm{MS}$, em indivíduos com má oclusão de Classe II, divisão 1. Métodos: mensuraram-se, em aparelho de precisão Assimetria I, 60 pares de modelos, de 27 indivíduos do sexo feminino e 33 do masculino, entre 12 e 21 anos de idade, com má oclusão de Classe II, divisão 1. Utilizando a sutura palatina mediana como referência de eixo de simetria, os modelos foram posicionados no aparelho para mensuração da distância entre a crista marginal mesial do molar mais distal e a crista marginal mesial do molar do lado oposto, a fim de verificar o posicionamento sagital dos molares. Em relação à giroversão, mediu-se a distância entre pontos na crista marginal mesial. O teste qui-quadrado a 5\% foi utilizado para verificar a variação de posicionamento dos molares, por arcos e por lado. O teste $t$ de Student a 5\% foi utilizado para comparar esses valores. Resultados: houve maior número de molares inferiores mesializados e, comparando os lados, maior número de molares mesializados no lado direito em ambas as arcadas. As rotações médias dos molares foram de $0,76 \mathrm{~mm}$ do lado direito e $0,93 \mathrm{~mm}$ do esquerdo. Conclusão: não houve diferença estatisticamente significativa entre os valores médios das mesializações dos molares quanto a lado ou arco. Quando observada isoladamente, a rotação dos molares, quantificada em milímetros, representou uma situação de $1 / 4$ de Classe II.

Palavras-chave: Dente molar. Má oclusão de Angle Classe II. Ortodontia.

${ }^{1} \mathrm{MSc}$ in Orthodontics, UMESP. Professor, Specialization Course in Orthodontics, APCD.

${ }^{2} \mathrm{PhD}$ Student, Oral Biopathology, UNESP.

${ }^{3} \mathrm{PhD}$ in Orthodontics, FOB/USP. Professor, UMESP.

${ }^{4} \mathrm{PhD}$ in Orthodontics, USP. Professor, UMESP.

${ }^{5}$ Post-Doc in Dentistry, UNICAMP. Adjunct Professor, Federal University of Sergipe.

" The authors report no commercial, proprietary or financial interest in the products or companies described in this article.
How to cite this article: Scanavini PE, Jóias RP, Vasconcelos MHF, Scanavini MA, Paranhos LR. Evaluation of the first molars sagittal and rotational position in Class II, division 1, malocclusion. Dental Press J Orthod. 2013 NovDec;18(6):106-11.

Submitted: September 13, 2011 - Revised and accepted: December 27, 2011

Contact address: Paulo Estevão Scanavini

Rua Antônio Pereira de Camargo, 129 - Centro

CEP: 13.170-030 - Sumaré/SP - E-mail: paranhos@ortodontista.com.br 


\section{INTRODUCTION}

Dental arch symmetry and dimension are of great interest for orthodontists when making diagnosis and treatment planning. ${ }^{1,2}$

Molar positioning in the anterior-posterior direction determines the sagittal classification of malocclusion $^{3,4}$ and can be easily detected in cases of Class II subdivision. However, molar positioning should also be considered in cases of bilateral malocclusion, since a molar more mesially positioned on one side, even if not clinically ${ }^{2}$ apparent, can influence diagnosis, treatment planning and, ${ }^{5-8}$ especially occlusal stability.

The asymmetric position may determine important aspects regarding the orthodontic mechanics that will be used, such as the correction of rotations, or distalization methods. ${ }^{9-12}$ These procedures may be applied with different intensities in each to obtain an arch with symmetrical positioning of the posterior teeth. ${ }^{13}$ With the purpose of carrying out a detailed assessment of teeth positioning, the dental cast analysis is an important tool due to its practicality, reliability and reproducibility. ${ }^{1,14-20}$

Thus, this study aimed at assessing the positioning of contralateral molars in the maxillary and mandibular arches in the anterior-posterior direction, as well as to examine the degree of rotation of the upper molars in individuals with Class II, division 1 malocclusion.

\section{MATERIAL AND METHODS}

This research was previously approved by the Institutional Review Board of the Metodista University of São
Paulo (UMESP), under protocol number 0210135 . The sample of this study was obtained from the files of the Postgraduate Program of the aforementioned University. Sixty sets of plaster models from 27 females and 33 males, aged between 12 and 21 years, with Class II, division 1 malocclusion, were selected.

Measurements were made directly in the study models by using Asymmetry I, a device developed in the Postgraduate Program Department to enable the visualization of the sagittal positioning of molars as well as the existence of possible rotations. This device consists of a structure similar to a parallelometer, containing: A base for positioning the model, a transparent horizontal acrylic plate with a millimeter ruler, and a rod which enables the identification of the molars positioning (Figs $1 \mathrm{~A}$ and $\mathrm{B}$ ).

The midpalatal suture was used as a symmetry reference. ${ }^{1,2}$ It was delimited in the maxillary arch by demarcating landmarks over the mid-palatal suture from the incisive papilla until the most posterior visible landmark. ${ }^{19,20}$ The symmetry axis was obtained by connecting these landmarks. Then, it was extended anteriorly up to the incisal edge of the maxillary incisor to determine the landmark As (anterior-superior). Conversely, it was posteriorly extended up to the posterior surface of the maxillary model to determine Ps (posterior-superior) (Fig 2A).

The midline projection, obtained in the maxillary arch, was used when the midpalatal suture was transferred to the lower model. ${ }^{15,16}$ The upper midline was transferred to the lower model by using the reference landmarks As and Ps.
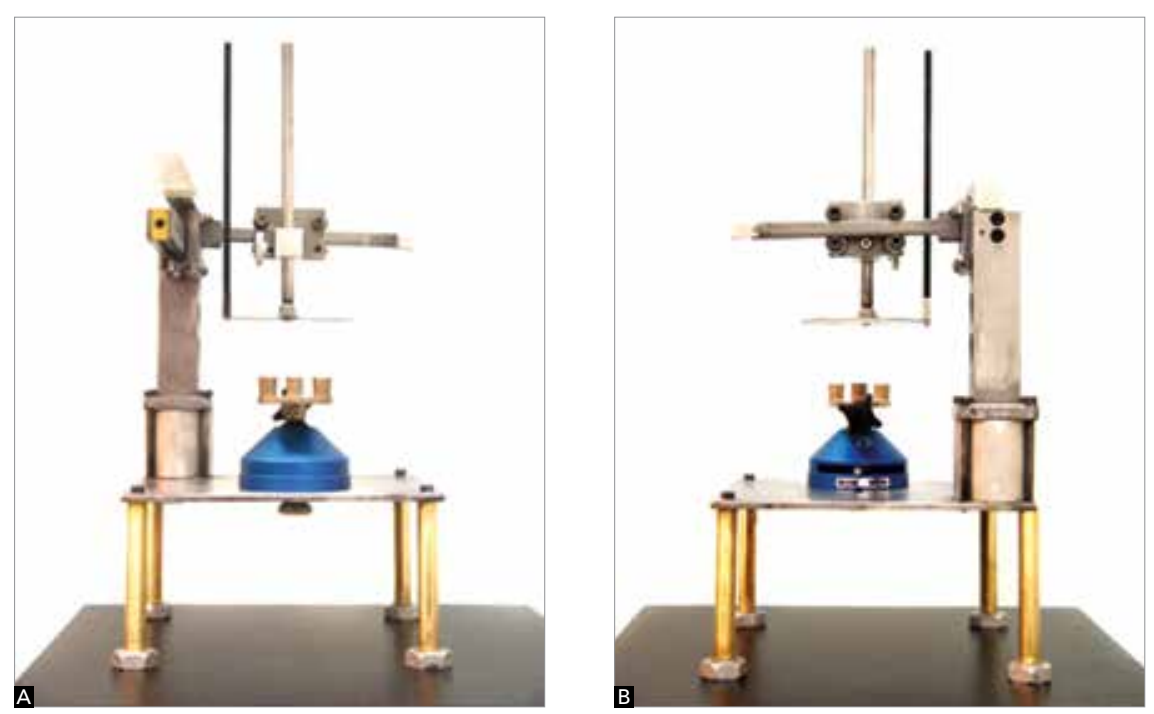

Figure 1 - Measuring device - Asymmetry I -, frontal view (A); posterior view (B) 
The models, properly trimmed, were placed in occlusion, so that the posterior surfaces matched in the same plane. The landmark Ps of the upper model was transferred to the lower model by means of a set triangle ruler positioned perpendicularly to the base of the lower model, thereby determining the landmark Pi (posterior-inferior) on the lower model (Fig 2B).

With the models still in occlusion and with the set triangle ruler equally placed anteriorly to the models matching with the landmark As of the upper model, the landmark Ai (anterior-inferior) was demarcated in the mandibular model (Fig 2C).

Obtaining and connecting $\mathrm{Ai}$ and Pi landmarks enabled the lower midline to be determined (Fig 2D).

The models were then placed onto the base of the parallelometer which was fixed to the base of the Asymmetry I device (Figs 3A and B). When positioning the models, the occlusal surface of the teeth should be parallel to the horizontal plane, and the protractor pointer positioned over the midpalatal suture. The reference used for assessing the molar positioning was the mesial marginal ridge. Subsequently, the distance between the mesial marginal ridge positioned more distally and the mesial marginal ridge of the opposite molar was measured in the longitudinal direction, as shown in Figures 4 and 5.
In order to verify the possible association of variation in molar positioning, concerning the arch and side of the molars mesially positioned, chi-square test $\left(\mathrm{c}^{2}\right)$ was used. Student's $t$ test was employed to compare these values. In all tests, a significance level of 5\% was adopted.

In addition to assessing the position of the molars in the anterior-posterior direction, the degree of rotation of the upper molars was also assessed, as follows: the distance between the most mesial portion of the mesial marginal ridge toward the mesiodistal sulcus (point CM), and the apex of the mesiobuccal cusp, at its most mesial portion, was measured. One horizontal line was projected from the CM landmark, and another from the VM landmark, both parallel. Thus, the distance between these lines was measured, in millimeters, indicating the rotation of the molars in the mesiodistal direction (Fig 6).

\section{RESULTS}

Table 1 shows the distribution of the individuals comprising the sample, considering the side of the molar mesially positioned and the dental arch.

The variation in the mean value of molar mesialization was found to be $0.05 \mathrm{~mm}$ for the maxillary arch, with mean values of $1.55 \mathrm{~mm}$ and $1.50 \mathrm{~mm}$ for the left and right sides, respectively. For the mandibular arch, this
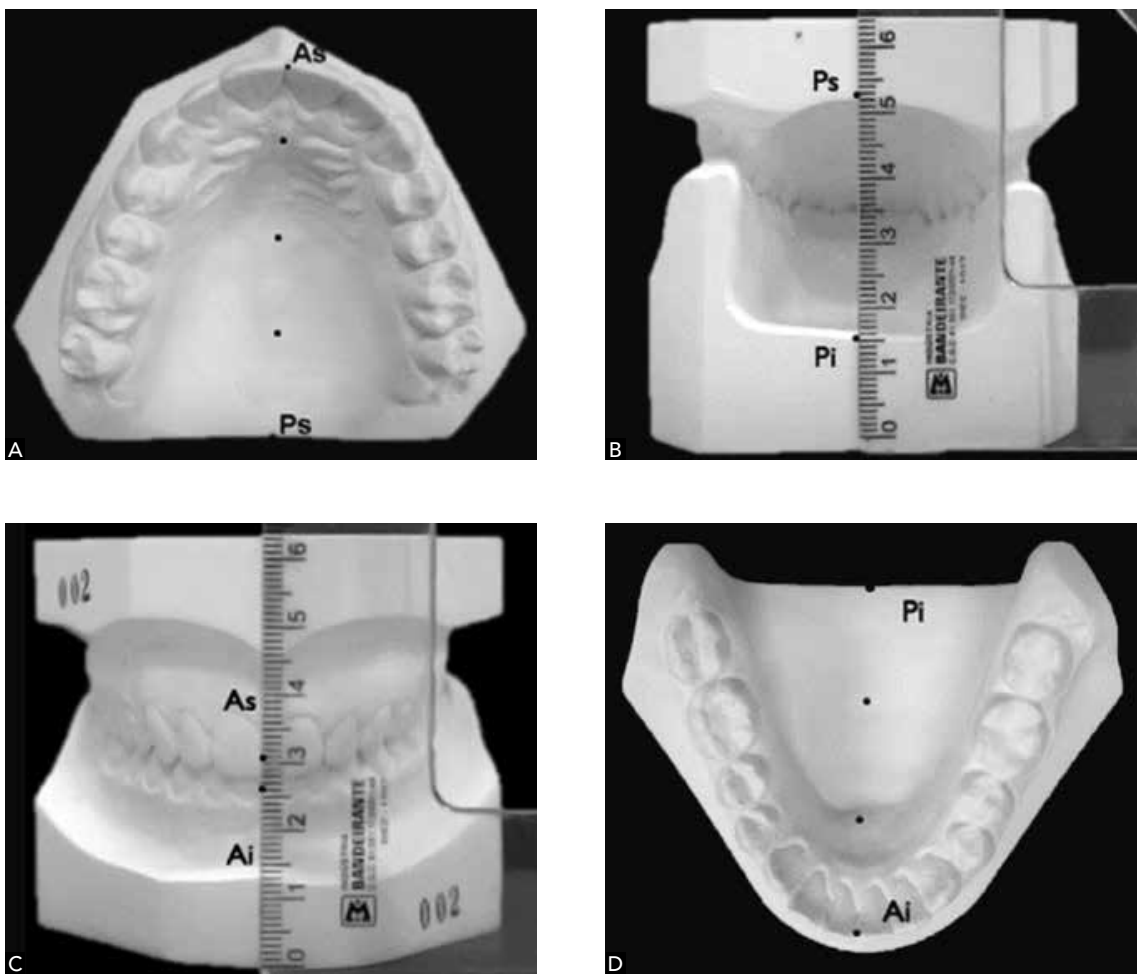

Figure 2 - A) determination of the upper midline (landmarks As and Ps); B) transference of the Ps to the lower model - obtaining $\mathrm{Pl}$; C) transference of the As landmark to the lower model obtaining $\mathrm{Ai}$; D) determination of the lower midline (landmarks Ai and Pi). 

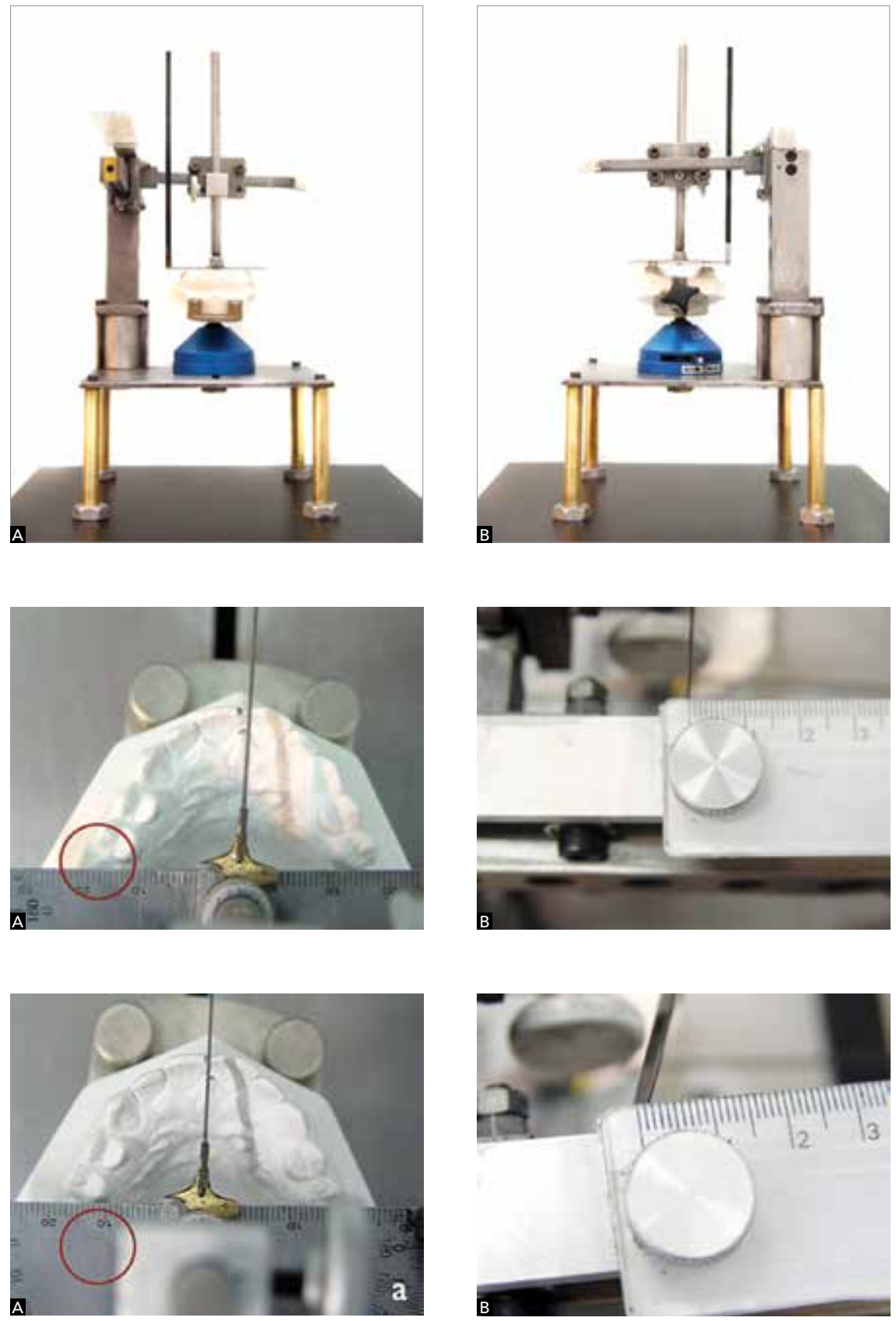

Rotation degree

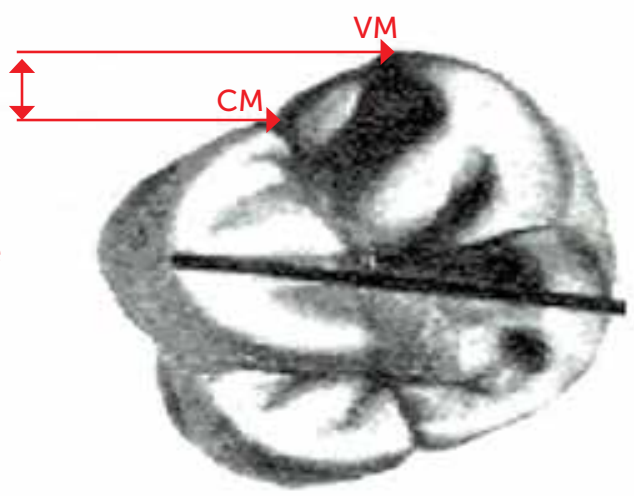

Figure 3 - Models positioned for measurement: A) front view, B) back view.

Figure 4 - A) Model positioned evidencing the more mesial position of the maxillary right first molar, in relation to left-side counterpart; B) ruler recording the position of the right maxillary first molar at zero position.

Figure 5 - A) Device positioned on the mesia marginal ridge of the right maxillary first molar B); ruler registering the most mesial position of the right maxillary first molar by $1.5 \mathrm{~mm}$, in relation to left-side counterpart.
Figure 6 - method used to assess the rotation of the first maxillary molars. 
variation was $0.45 \mathrm{~mm}$, with mean values of $2.19 \mathrm{~mm}$ and $1.74 \mathrm{~mm}$ for the left and right sides, respectively. Table 2 shows the mean values and respective standard deviation of molar mesialization with regard to the arch and side. The $t$ test indicated no significant difference in the respective comparisons.

With regard to the rotation of the upper molars, mean rotations of $0.76 \pm 0.37 \mathrm{~mm}$ and $0.93 \pm 0.53 \mathrm{~mm}$ were observed for the right and left molars, respectively, and a mean rotation of $0.85 \pm 0.45 \mathrm{~mm}$ was observed between both sides.

\section{DISCUSSION}

The models used herein were assessed by a device exclusively developed for the dental arch asymmetry analyses. It was carefully designed not only to allow the models to be positioned on a flat surface, but also to observe the inclination of the occlusal plane. Additionally, it was used a small-caliber rod $(0.5 \mathrm{~mm})$ to avoid improper interferences on the measurements. ${ }^{14-17}$

In order to achieve more accurate and standardized measures, the models were placed onto a parallelometer base fixed to the base of the device, considering the midpalatal suture as a symmetry reference. ${ }^{1,2}$ The occlusal surfaces of the teeth on the models were leveled to the horizontal plane by means of a leveling board. Two-millimeter rulers were adapted, one on

Table 1 - Distribution of the individuals comprising the sample considering the side of the molar mesially positioned and arch.

\begin{tabular}{|c|c|c|c|c|}
\hline \multirow{3}{*}{ Mesialization } & \multicolumn{4}{|c|}{ Arch } \\
\hline & \multicolumn{2}{|c|}{ Maxillary } & \multicolumn{2}{|c|}{ Mandibular } \\
\hline & $n$ & $\%$ & 27 & 45,0 \\
\hline Right molar & 21 & 35.0 & 27 & 45.0 \\
\hline Without mesialization & 29 & 48.3 & 17 & 28.3 \\
\hline Left molar & 10 & 16.7 & 16 & 26.7 \\
\hline Total & 60 & 100.0 & 60 & 100.0 \\
\hline
\end{tabular}

the protractor base, and the other on the upper part of the device as a way to measure the positioning and degree of rotation of the molars. The part of the device where the protractor with the pointer was fixed could move in transverse and longitudinal directions, through a set of rollers, causing the measurements to be easily and agilely obtained, thus, permitting higher reliability and standardization — once the models remained static after been positioned, and only the protractor with the pointers could move.

The analysis of the results demonstrated that the comparison between maxillary and mandibular arches showed a great number of lower molars more mesially positioned, corroborating the literature, ${ }^{15,21,22}$ while the comparison between the sides showed a higher number of molars mesially positioned on the right side of both arches.

The mean values regarding variation in molar mesialization suggest that the sample of this study showed greater variation in molar positioning in the mandibular arch, which leads to a high incidence of asymmetry. This fact occurs because the mesialization of a molar in relation to its counterpart reveals an asymmetric positioning of these teeth, which can also indicate asymmetry in the respective dental arch. Although numerical differences were observed with regard to the sagittal positioning of these molars, our results pointed out that the mean values and standard deviation of molar mesialization have no significant difference when compared between the arches, neither when compared to the side of the molar mesially positioned. These findings are in disagreement with those of other authors ${ }^{15,16,21}$ who assessed dental asymmetry in individuals with the same malocclusion and found significant differences between the maxillary and mandibular arches.

Asymmetric positioning of molars can be attributed to genetic, postural, chewing and harmful habits. ${ }^{1,67,21}$ A correct diagnosis and adequate treatment planning are of paramount importance for obtain-

Table 2 - Mean value and standard deviation of molar mesialization with regard to the arch and side, and test values for the respective comparisons.

\begin{tabular}{ccccc}
\hline & Left & Right & Comparison between sides \\
\hline Mean \pm SD & $1.55 \pm 0.76$ & $1.50 \pm 0.50$ & 0.219 \\
\hline Mandibular & $2.19 \pm 1.12$ & $1.74 \pm 0.96$ & 0.828 (ns) \\
\hline Comparison between the arches & $t=1,576 ;$ & $p=0.128$ (ns) & $t=1.039 ;$ & $p=0.304$ (ns) \\
\hline
\end{tabular}

ns - non-significant difference. 
ing a stable occlusion at retention and post-retention stages. In addition, achieving a symmetrical positioning of molars at an early stage of the orthodontic treatment favors the success of such a treatment. ${ }^{6,7,8}$

With regard to factors that possibly influence the asymmetric positioning of molars, the rotation of maxillary molars was assessed. This rotation may indicate an increased length of the maxillary dental arch, besides being responsible for the Class II relationship of molars. Accordingly, it is justified the need to assess the rotation of the first maxillary molars, once the degree of rotation may determine the level of Class II malocclusion. The correction of rotation of the first maxillary molars can even transform a Class II molar relationship into a Class I molar relationship, depending on the degree of rotation of the first maxillary molars.

This study aimed at assessing the rotation of molars in millimeters, i.e., foreseeing the space that would be gained in the dental arch so that the molars would be driven to the ideal position. The mean values of rotation of the molars were found to be $0.76 \mathrm{~mm}$ and $0.93 \mathrm{~mm}$ for the right and left molars, respectively.

In general, the literature quantifies Class II into $1 / 4$ or $1 / 2$ Class II, or full Class II. Taking into account that the average mesiodistal width of an upper molar is $10.41 \mathrm{~mm}^{23}$ and that the average rotation of the molars was $0.84 \mathrm{~mm}$, it was possible to understand that the molar rotation observed herein, when singly considered, would correspond to $1 / 4$ of Class II.

\section{CONCLUSION}

In conclusion, the results obtained by the methodology applied showed that:

" No significant difference was detected between the mean values and standard deviation of the molars mesialization when compared per side (right and left) and per arch (maxillary and mandibular);

"When singly observed, the molar rotation, quantified in millimeters, accounted for $1 / 4$ of Class II.

\section{REFERENCES}

1. Lundstrom A. Some asymmetries of dental arches, jaws, and skull, and their etiological significance. Am J Orthod. 1961;47(2):81-106.

2. Lear C. Symmetry analyses of the palate and maxillary dental arch. Angle Orthod. 1968;38(1):56-62.

3. Angle EH. Classification of malocclusion. Dent Cosmo. 1899;41(3):248-64.

4. Andrews LF. The six keys to normal occlusion. Am J Orthod. 1972; 62(3):296-309.

5. Nery PCB, Barbosa JA. Rotação de primeiros molares superiores na oclusão normal e má oclusão de Classe II divisão 1 de Angle. Rev Dental Press Ortod Ortop Facial. 2003:8(5):101-12.

6. Burstone CJ. Diagnosis and treatment planning of patients with asymmetries Semin Orthod. 1998;4(3):153-64.

7. Shroff B, Siegel SM. Treatment of patients with asymmetries using asymmetric mechanics. Semin Orthod. 1998:4(3):165-79.

8. Paranhos LR, Andrews WA, Jóias RP, Bérzin F, Daruge Júnior E, Triviño T. Dental arch morphology in normal occlusions. Braz J Oral Sci. 2011; 10(1):65-8

9. Moscardini MS. Estudo comparativo da eficiência do aparelho extrabucal e da barra transpalatina como meios de ancoragem durante a fase de retração. Rev Dental Press Ortod Ortop Facial. 2007:12(2):86-95.

10. Shimizu RH, Ambrosio RA, Shimizu IA, Godoy-Bezerra J, Ribeiro JS, Staszak KR. Principios biomecânicos do aparelho extrabucal. Rev Dental Press Ortod Ortop Facial. 2004; 9(6):122-56.

11. Dahlquist A. The effect of a transpalatal arch for the correction of first molar rotation. Eur J Orthod. 1996:18(3):257-67.
12. Choi YJ, Lee JS, Cha JY, Park YC. Total distalization of the maxillary arch in a patient with skeletal Class II malocclusion. Am J Orthod Dentofacial Orthop 2011;139(6):823-33.

13. Quaglio LC, Freitas KMS, Freitas MR, Janson G, Henriques JFC. Stability and relapse of maxillary anterior crowding treatment in Class I and Class II division 1 malocclusions. Am J Orthod Dentofacial Orthop. 2011:139(6):768-74.

14. Wertz RA. Diagnosis and treatment planning of unilateral Class II malocclusions. Angle Orthod. 1975:45(2):85-94

15. Araújo TM. Skeletal and dental arch asymmetries in individuals with normal dental occlusion. Int J Adult Orthod Orthog Surg. 1994;9(2):111-8.

16. Araújo TM. Skeletal and dental arch asymmetries in Class II division 1 malocclusion. J Clin Pediatr Dent. 1994;18(3):181-5.

17. Korkhaus G. A new orthodontic symmetrograph. Int J Orthod Oral Surg Radiol. 1930;16(6):665-8.

18. Mucha JN, Bolognese AM. Análise de modelos em Ortodontia. Rev Bras Odontol. 1985;42(1):28-44.

19. Maurice TJ, Kula K. Dental arch asymmetry in the mixed dentition Angle Orthod. 1998;68(1):37-44

20. Alavi DG. Facial and dental arch asymmetries in Class II subdivision malocclusion. Am J Orthod Dentofacial Orthop. 1988:93(1):38-46.

21. Janson GR. Assimetria dentária e suas complicações no tratamento ortodôntico: Apresentação de um caso clínico. Ortodontia. 1995;28(3):68-73.

22. Rose JM. Mandibular skeletal and dental asymmetry in Class II malocclusions. Am J Orthod Dentofacial Orthop. 1994;105(5):489-95.

23. Jóias RP, Velasco LG, Scanavini MA, Miranda ALR, Siqueira DF. Evaluation of the Bolton ratios on 3D dental casts of Brazilians with natural normal occlusions. World J Orthod. 2010;11(1):67-70 